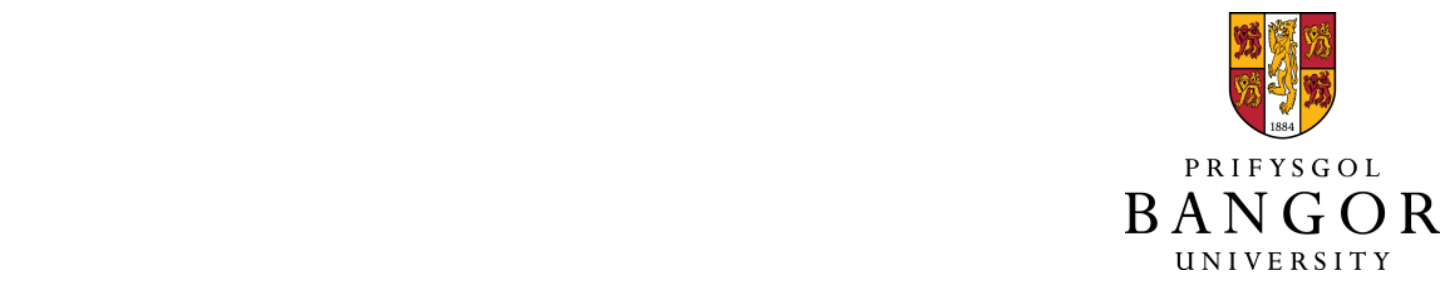

The effect of light on bacterial activity in a seaweed holobiont

Coelho-Souza, Sergio; Jenkins, Stuart; Casarin, Antonio; Baeta-Neves, Maria ; Salgado, Leonardo; Guimaraes, Jean ; Coutinho, Ricardo

Microbial Ecology

DOI:

$10.1007 / \mathrm{s} 0024$

Published: 01/11/2017

Peer reviewed version

Cyswllt i'r cyhoeddiad / Link to publication

Dyfyniad o'r fersiwn a gyhoeddwyd / Citation for published version (APA):

Coelho-Souza, S., Jenkins, S., Casarin, A., Baeta-Neves, M., Salgado, L., Guimaraes, J., \& Coutinho, R. (2017). The effect of light on bacterial activity in a seaweed holobiont. Microbial Ecology, 74(4), 868-876. https://doi.org/10.1007/s0024

\footnotetext{
Hawliau Cyffredinol / General rights

Copyright and moral rights for the publications made accessible in the public portal are retained by the authors and/or other copyright owners and it is a condition of accessing publications that users recognise and abide by the legal requirements associated with these rights.

- Users may download and print one copy of any publication from the public portal for the purpose of private study or research.

- You may not further distribute the material or use it for any profit-making activity or commercial gain

- You may freely distribute the URL identifying the publication in the public portal ?
}

Take down policy

If you believe that this document breaches copyright please contact us providing details, and we will remove access to the work immediately and investigate your claim. 


\title{
The effect of light on bacterial activity in a seaweed holobiont
}

\author{
Sergio A. Coelho-Souza ${ }^{1,2, *}$, Stuart R Jenkins ${ }^{3}$, Antônio Casarin ${ }^{1}$; Maria Helena Baeta-Neves ${ }^{1}$, Leonardo \\ T Salgado ${ }^{4}$, Jean R.D. Guimaraes ${ }^{2}$, Ricardo Coutinho ${ }^{1}$
}

${ }^{1}$ Instituto de Estudos do Mar Almirante Paulo Moreira (IEAPM-RJ); ${ }^{2}$ Universidade Federal do Rio de Janeiro (LTWCP/IBCCF/UFRJ); ${ }^{3}$ School of Ocean Sciences (Bangor University); ${ }^{4}$ Instituto de Pesquisas Jardim Botânico do Rio de Janeiro (IPJBRJ)

*Present addresses: Universidade Federal do ABC; Centro de Ciências Naturais e Humanas; Bloco Delta, Sala 222; Rua Acturus 03; Jardim Andares, São Bernardo do Campo - SP, CEP: 09606-070/ Centro de Biologia Marinha (CEBIMAR/USP); Rodovia Manoel Hypólito do Rego, km 131,5 São Sebastião - SP, CEP 11612-767

Email adresses: sergio.coelhosouza@gmail.com; sacs@biof.ufrj.br

\section{Abstract}

Holobionts are characterized by the relationship between host and their associated organisms such as the biofilm associated with macroalgae. Considering that light is essential to macroalgae survival, the aim of this study was to verify the effect of light on the heterotrophic activity in biofilms of the brown macroalgae Sargassum furcatum during its growth cycle. Measurements of heterotrophic activity were done under natural light levels at different times during a daily cycle and under an artificial extinction of natural light during the afternoon. We also measured Sargassum primary production under these light levels in the afternoon. Both measurements were done with and without photosynthesis inhibitor and antibiotics. Biofilm composition was mainly represented by bacteria but diatoms, cyanobacteria and other organisms were also common. When a peak of diatom genera was recorded, the heterotrophic activity of the biofilm was higher. Heterotrophic activity was usually highest during the afternoon and the presence of a photosynthesis inhibitor caused an average reduction of $17 \%$ but there was no relationship with Sargassum primary production. These results indicate that autotrophic production in the biofilm was reduced by the inhibitor with consequences on bacterial activity. Heterotrophic activity was mainly bacterial and the antibiotics chloramphenicol and penicillin were more effective than streptomycin. We suggest primary producers in the biofilm are more important to increase bacterial activity than the macroalgae itself because of coherence of the peaks of heterotrophic and autotrophic activity in biofilm during the afternoon and the effects of autotrophic inhibitors on heterotrophic activity.

Keywords: prokaryotic-eukaryotic interaction; sun light; autotrophic-heterotrophic production; leucine incorporation; specific metabolic inhibitors; Brazilian upwelling 
Biofilms are ubiquitous features of any immersed surface in aquatic environments including the surfaces of living organisms [35]. Macroalgae or seaweeds provide a highly attractive surface for the development of microbial biofilms; not only do they provide a solid surface for attachment but they also release large amounts of organic carbon which can be utilised by microorganisms [1]. Hence macroalgae support complex and highly dynamic microbial communities. Understanding of the interaction between these predominantly prokaryotic communities and the seaweeds on which they grow is relatively poor [13]. This is surprising given that the seaweed/biofilm system potentially provides an ideal model to explore the interface between eukaryotic and prokaryotic ecology and specifically to examine the bi-directional relationship between holobiont partners [32].

The relationship between seaweeds and prokaryotes can operate in a positive and negative sense for both partners [13]. For example, algal products such as dissolved organic matter can stimulate prokaryotic activity [15] but algae can also produce compounds which are toxic to prokaryotes [21]. Products derived from epiphytic prokaryotes such as $\mathrm{CO}_{2}$, fixed nitrogen and specific growth factors can benefit macroalgal photo-autotrophy and growth $[9 ; 19]$. In this holobiont model, biological,

61 chemical and physical surface properties of seaweeds, which may be determined by 62 factors such as environmental conditions and seaweed age, have an important role in determining the composition and activity of prokaryotic communities [2]. In addressing the nature and direction of the relationship between prokaryote 65 biofilms and eukaryotic seaweeds, one profitable approach can be through 
measurements of prokaryotic heterotrophic activity by the ${ }^{3} \mathrm{H}$-leucine incorporation technique [5]. Using Sargassum as a biological model, the use of specific inhibitors showed that biofilm heterotrophic activity was mainly bacterial. However, the effect of different antibiotics were tested only in laboratory conditions. In addition, bacterial activity was also inhibited by an eukaryotic inhibitor in dark conditions, suggesting a symbiotic relationship between eukaryotes and prokaryotes in the Sargassum model. Finally, bacterial activity was higher when incubations were done in field conditions than in the laboratory, suggesting that natural solar light could be also important to the heterotrophic prokaryotic production. Thus, it is possible that bacterial activity is associated with algal autotrophic production that could change during the daily cycle and by light intensity.

Using Sargassum furcatum as a seaweed holobiont model, the aim of this work was to determine if: 1) bacterial activity in the biofilm is associated with algal autotrophic production; 2) varies seasonally; 3) varies over the day-night cycle as well as 4) under different light intensities in the afternoon; and 5) different antibiotics have different effects on the bacterial activity. In a series of experiments performed monthly using different ages of Sargassum, we also evaluated environmental conditions, observed biofilm by microscopy and compared biofilm bacterial activity with or without a photosynthesis inhibitor.

Materials and Methods

\section{Sargassum Sampling}


area on the Brazilian coast located in the Cabo Frio region of Rio de Janeiro state [details in 7]. Sampling was undertaken monthly in a Sargassum bed at 4-6 m depth at the Farol beach station, Cabo Frio Island, between November 2007 and April 2008. Physico-chemical water variables (nutrients, chlorophyll, temperature and salinity) were available over the period of study through the weekly monitoring of the Brazilian navy (Instituto de Estudos do Mar Almirante Paulo Moreira - IEAPM) and methods used are described elsewhere [6]. Solar light radiation was measured every 5 minutes during all experimental periods using a LICOR LI-1.000 Datalogger/Li-193 SA spherical quantum sensor.

Specimens of Sargassum furcatum were collected and selected by size over its growth cycle from November to April [26]. Therefore, individuals up to $5 \mathrm{~cm}$ were sampled in November; between 5 and $15 \mathrm{~cm}$ in December; between 10 and $20 \mathrm{~cm}$ in January; between 15 and $25 \mathrm{~cm}$ in February; between 15 and $30 \mathrm{~cm}$ in March and; up to $10 \mathrm{~cm}$ in April, representing the end of its life cycle. Five individuals in the size classes described above were collected at random within the Sargassum bed and transferred in polyethylene pots $(500 \mathrm{~mL})$ to the laboratory approximately $200 \mathrm{~m}$ away. Biofilm composition was observed by epiflourescence and scanning electron microscopy. Blades of each Sargassum individual were used for microscopic observations $(n=5)$ as well as for measurements of bacterial activity $(n=5)$. A pilot study showed no statistical difference in bacterial activity using 5 or 15 replicates.

\section{Experimental conditions}

Bacterial activity was measured at all six sampling dates. To understand the daily pattern of heterotrophic production, measures were made at different times of the 
day during the afternoon (12:00 - 15:00), evening (18:00 - 20:00), night (23:00 01:00) and morning (07:00 - 09:00) at each sampling event. Light levels vary over this 24 hour cycle but co-vary with other factors including temperature and internal diel rhythms. Thus to unambiguously determine the effect of light, measures were made at the time of peak light levels during the afternoon (12:00 - 15:00) over a light extinction sequence using an artificial reduction of natural light $(100 \%, 75 \%, 50 \%, 25 \%, 10 \%$, $1 \%$ and $0 \%$ ) using different levels of a black mesh.

All measures of activity were made in the sea at a depth of approximately $0.5 \mathrm{~m}$, using a submerged platform supporting an open ended acrylic tube into which algal material was placed. One blade of approximately $1 \mathrm{~cm}^{2}$ from each plant $(\mathrm{n}=5)$ were incubated in separate $2-\mathrm{mL}$ microcentrifuge tubes (eppendorf) with local $0.22-\mu \mathrm{m}$ filtered water held within a 125-ml Winkler bottle. The dry weight in each $\mathrm{cm}^{2}$ of Sargassum blade was $0.004 \pm 0.001 \mathrm{~g}$.

For autotrophic production, five blades were inserted into one $125 \mathrm{~mL}$ glass Winkler bottle with local $0.22-\mu \mathrm{m}$ filtered water to have an amount of algal biomass that could be detected by the method used. In November, the measurement was determined by the mean of three Winkler bottles since there was no experimental treatment. In the other months, two treatments were tested (with and without specific inhibitors) and photosynthesis incubation was done in three bottles $(n=3)$.

To directly test the relationship between autotrophic production and bacterial activity a photosynthesis inhibitor $(10 \mu \mathrm{M}$ diuron) was used at four of the sampling dates at each of the four times of day (Table 1). Bacterial activity was thus compared when photosynthesis was naturally occurring and when inhibited. We also tested different antibiotics in November, January and March (through comparing bacterial activity with and without the use of antibiotics at the sampling dates): $5 \mu$ g.L ${ }^{-1}$ 
141 streptomycin +100 units. $\mathrm{L}^{-1}$ penicillin were used in November, $5 \mu \mathrm{g} . \mathrm{L}^{-1}$ streptomycin were used in January and $0.2 \mathrm{nM}$ chloramphenicol in March samplings (Table 1).

Bacterial activity

Bacterial activity was determined using an adaptation of the ${ }^{3} \mathrm{H}$-leucine incorporation technique [5] following a methodology for periphyton associated with macrophyte roots [23]. Briefly, blades of approximately $1 \mathrm{~cm}^{2}$ were incubated in 2.0 $\mathrm{mL}$ eppendorf with $35 \mathrm{nM}{ }^{3} \mathrm{H}$-leucine in $1.5 \mathrm{~mL}$ of $0.22-\mu \mathrm{m}$ filtered water $(\mathrm{n}=5)$. The incubation time was $1.5-3 \mathrm{~h}$ and $80 \mu \mathrm{L}$ of $100 \%$ trichloroacetic acid (TCA) was used to stop the incubation. In addition all experiments were performed using a killed control where production was terminated at the start by adding $5 \%$ TCA just before the input of ${ }^{3} \mathrm{H}$-leucine. Following incubation, samples were frozen until protein extraction. Extraction started with a 5-min sonication bath, and then the blade was removed. Samples were centrifuged at 2,500 g for $15 \mathrm{~min}$, and the supernatant was transferred to a new microcentrifuge tube before being centrifuged again at $13,000 \mathrm{~g}$ for $10 \mathrm{~min}$, after which time the supernatant was discarded; $1.5 \mathrm{~mL}$ of cold TCA (5\%) was added, and the centrifugation process was repeated. One milliliter of $80 \%$ ethanol was added, and a new centrifugation was done. Finally, $1 \mathrm{~mL}$ of scintillation cocktail (Cytoscint) was added and, after an overnight period, radioassayed by scintillation counting (TRICARB PACKARD 1600) for $30 \mathrm{~min}$ or after the accumulation of 10,000 counts [as determined by 6]. Leucine incorporation rate (in moles per squared meter per hour) was calculated considering net disintegrations per minute (DPM), sample area $\left(1 \mathrm{~cm}^{2}\right)$, leucine concentration, ${ }^{3} \mathrm{H}$-leucine specific activity $\left(72 \mathrm{Ci} \cdot \mathrm{mmol}^{-1}\right)$ and time of incubation. 

incubated in $125 \mathrm{~mL}$ glass Winkler bottles with local $0.22-\mu \mathrm{m}$ filtered water. It is important to mention that blades were not axenic since they were sampled from the natural bed. Hence both microautotrophs and heterotrophs were included in both production and consumption of carbon. Oxygen was fixed to determine its initial concentration. A dark control was used to determine oxygen consumption, and a glass with no blade of Sargassum was used to verify phytoplankton production. Then, primary production was determined using the Winkler method after 2-3 $\mathrm{h}$ of incubation stopped with oxygen fixation [27]. The results were calculated considering the difference of oxygen between the end and the beginning of the experiment divided by the total dry weight of the five blades and the time of incubation $\left(\mathrm{ngC} \cdot \mathrm{gdw}^{-1} \cdot \mathrm{h}^{-1}\right)$. The photosynthetic coefficient was between $0.98-1.01$ [31].

Statistical analysis

Two way ANOVA was done considering all factors as fixed and orthogonal and

a 0.1 significance level. 4 levels were used for the factor time of day (morning, afternoon, evening and night), 7 levels for the factor light incidence (100, 75, 50, 25, 10, $1,0 \%$ ) and two levels for the factor inhibitor (with or without). When necessary, data were log transformed and analyses run using WinGmav software (version 5.0). In the experiments at different times of the day, November was omitted owing to lack of measurement in the morning time. Multiple comparisons of levels within significant factors were made using Student Newman Keuls (SNK) tests. 
Results

193

Environmental conditions during the experiments

195

All environmental conditions during sampling can be found in Tables 2 and 3.

Light intensity (at approximately $0.5 \mathrm{~m}$ depth) was high during the afternoon and morning experiments except in December and January when it was approximately one thousand times lower compared to the other months. During this time, a bloom of phytoplankton was visually observed and the Sargassum bed was not visible from the boat ( $4 \mathrm{~m}$ above) during arrival at the experimental area in the morning before the experiment began. In addition, pheophytin concentrations peaked in December and January $\left(2.8\right.$ and $1.3 \mathrm{mg} / \mathrm{m}^{3}$, respectively) and chlorophyll $a$ in December $\left(1.7 \mathrm{mg} / \mathrm{m}^{3}\right)$. For nutrients, nitrate was highest in February $(3.1 \mu \mathrm{mol} / \mathrm{L})$ and below the detection limit in April. Peak of ammonia was observed in November $(1.8 \mu \mathrm{mol} / \mathrm{L})$ and, of phosphate and of nitrite in December (0.6 and $0.4 \mu \mathrm{mol} / \mathrm{L}$, respectively). degrees among months (Table 2). Surface water temperatures over 24 hours were around $20.6{ }^{\circ} \mathrm{C}$ during the experiments of November and around $23.3{ }^{\circ} \mathrm{C}$ in December but ranged from 25.3 to $23.0{ }^{\circ} \mathrm{C}$ in February, 27.2 to $24{ }^{\circ} \mathrm{C}$ in March and 25.5 to 24.4 ${ }^{\circ} \mathrm{C}$ in April. In January, upwelling was more intense during sampling since water temperature was below $18{ }^{\circ} \mathrm{C}$ in the Sargassum bed at 4-6 m depth.

Biofilm composition includes both autotrophic and heterotrophic organisms such as bacteria, phytoflagellates, diatoms, hydrozoans, cyanobacteria and eukaryotic algae. 
Nitzschia, Licmophora and Striatella (Baeta-Neves pers. obs.). SEM images showed high abundance of bacterial rods and Cocconeis diatoms as well as EPS production (Supplementary material).

Daily and seasonal bacterial activity

Bacterial activity showed little obvious seasonal variation when measured in the evening, night-time and morning. When measured in the afternoon it showed a rapid increase from very low levels in November to a peak of over $300 \mathrm{pgC} . \mathrm{cm}^{-2} \cdot \mathrm{h}^{-1}$ in January followed by a gradual decline over the following months (Fig. 1). Two way ANOVA revealed a significant interaction between the factors month and time of experiment $(\mathrm{p}=0.04)$ and SNK confirmed that bacterial activity was significantly highest during the afternoon of January. However, bacterial activity in January was only significantly higher than April $(\mathrm{p}=0.014)$ and independently of season, activity was significantly highest during the afternoon $(\mathrm{p} \leq 0.001)$. relationship with Sargassum autotrophic production

To check if bacterial activity is influenced by light intensity in the afternoon a series of experiments simulating different degrees of light intensity was done in each month during the Sargassum growth cycle. Considering each month no obvious pattern was observed among treatments (Fig. 2). However, ANOVA and SNK tests revealed that heterotrophic activity was highest under low light conditions in the experiments of 
241 intensity, the highest activity was also observed under low light conditions (Fig. 2). In

242 addition, there was no evident relationship between Sargassum primary production and

243 the bacterial activity in the biofilm.

The effect of specific metabolic inhibitors

The use of $10 \mu \mathrm{M}$ diuron in February and April inhibited Sargassum autotrophic production completely (data not shown) and its effect on bacterial activity was variable

(Table 4). In the experiments conducted at different times of day done in November,

December, February and April, the presence of diuron reduced heterotrophic activity between 0 to $66 \%$ (in average $17 \pm 11 \%$ ). ANOVA revealed a significant interaction in December $(\mathrm{p}=0.002)$ when the presence of diuron reduced bacterial activity significantly during the afternoon and night-time; and in April $(\mathrm{p}=0.008)$ when heterotrophic activity reduced significantly during the night-time and in the morning (Fig. 4). The effect of diuron on heterotrophic activity in the experiments simulating light in November (Table 4).

Antibiotics had different actions on both autotrophic and heterotrophic activities. While penicillin with streptomycin completely inhibited photosynthesis of Sargassum and the heterotrophic activity in biofilm (data not shown), the effect of streptomycin alone was light-dependent since the significant reduction of both measurements were observed only under $50 \%$ of light in the experiment conducted in January (Fig. 6). light-dependent effect on Sargassum photosynthesis; stopping its activity under high 
lights conditions (Fig. 4).

\section{Discussion}

Studies on the ecology of seaweed holobionts aim to understand the mechanism and function of all microbial members and their ecological role in the alga's life cycle. However, manipulative experiments in field conditions are challenging [11]. Our observations of the Sargassum furcatum holobiont model in its natural environment showed that biofilm composition varied with algal age and with environmental conditions; such variation potentially plays an important role in determining bacterial activity. However, we could not separate the effects of specific environmental conditions from the plant size and age. Observations at different times of the day showed that bacterial activity consistently peaked in the afternoon, when light levels were highest suggesting an association of heterotrophic and autotrophic productions. However, there was no relationship between bacterial activity and light intensity during the afternoon and no obvious correlation between Sargassum primary production and the bacterial activity in its biofilm. More studies are need to check if Sargassum also incorporate leucine. Nevertheless, our results showed some evidence of a negative effect of a photosynthesis inhibitor on bacterial activity and the highest activity occurred when diatoms were more abundant suggesting that heterotrophs may be stimulated by the autotrophic production in biofilm. Such prokaryotic-eukaryotic coupling is expected in a healthy holobiont system highlighted herein by the effect of antibiotics on both heterotrophic and autotrophic activities.

In the studied region, upwelling events are seasonal and Sargassum growth occurs as a function of its intensity [14]. Thus, upwelling should be considered an 
291 important factor causing turnover in community composition of the benthic 292 environment but also of planktonic prokaryotes [4] and eukaryotes [34] which are able 293 to colonize the surface of macroalgal blades [5]. It is expected that Sargassum also 294 selects its biofilm composition since Sargassum produces compounds with antioxidant, 295 antibacterial, antitumoral, antimalarial, antiherbivory and antifouling properties [e.g. 28] 296 but the concentrations of these compounds may reduce as algae age [10]. We also observed using SEM images the presence of holes indicating that settled organisms detached early increasing spatial heterogeneity and forming new habitats and niches [2] that could enhance productivity [3]. We suggest a higher niche overlap on the youngest blades when higher competition decreased bacterial activity [12] and the peak of activity in January could be associated not only with a more stable habitat but also with the subsequent increase in diatom abundance and diversity. Such increases could enhance bacterial activity by provision of diatom metabolic products. The reduction in bacterial activity after the peak in January could be a function of both diatom detachment and the regressing of Sargassum blades (increasing polymer degradation) leading to a reduction in autotrophic enhancement.

Bacterial activity peaked in the afternoon and we suggest its association with bioactive secondary metabolites as a consequence of photosynthesis [11] as well as with microalgal-(nutrient)-leakage after a day of photosynthesis [22] since it peaked during a phytoplankton bloom under an upwelling event. It is known that biofilm conditions vary in the contrasting light circumstances over a day [31] and seasonal variations in the biofilm conditions are strictly associated with light [18]. In addition, bacterial growth is usually higher during daylight hours [17] and the effect of antibiotics showed herein point to Bacteria being the major group incorporating leucine in our measurements, confirming observation in laboratory assays [5]. Similar observations have been made 
in freshwater epiliphic biofilms, where bacterial biomass and activity was highest in the presence of light as a consequence of organic substrates produced by algae [29]. Thus, we suggest that exudation is an important factor for coupling algal primary productivity and bacterial activity in a seaweed holobiont model.

We cannot affirm if diatoms increased bacterial activity because of facilitation or by character displacement, since both enhance productivity over time $[12 ; 20]$ and we did not measure important biotic factors such as competition, predation and herbivory $[22 ; 25 ; 30]$. In contrast, the importance of microalgal exudation is partially supported by the effect of photosynthesis inhibitor on bacterial activity. The wide variation in the effect of diuron could be associated with the ability of biofilms to decrease the action of many compounds [8] but also with the direct relationship between grazing pressure on bacteria and the concentration of exudates [22]. However, our results support the hypothesis that on average $17 \%$ of the autotrophic production in the biofilm is used by bacteria in the Sargassum holobiont model.

Our results, showing different degrees of antibiotic effects, corroborate the work of Nair et al. [24] that showed marine bacteria to be less sensitive to streptomycin than to penicillin and chloramphenicol. Additionally, our results showed a light-dependent effect of streptomycin and chloramphenicol on photosynthesis; such effects may not only be related to their antibiotic properties. Both are directly associated with photoinhibition since they inhibit photosystem II photosynthetic efficiency. Hader et al. [16] showed inhibition of D1 protein biosynthesis in chloroplast of seaweeds, using almost the same concentrations of both substances as in our study $(500 \mu \mathrm{g} / \mathrm{mL}$ and 2 $\mathrm{mg} / \mathrm{mL}$, for streptomycin and chloramphenicol respectively). D1 protein controls electron transport after primary photon absorption and is inhibited by visible and UV lights. 
In future studies, we recommend the determination of 1) the importance of periphytic algae to the attached bacterial production and of 2) the specific effect of plant size and environmental conditions in the experimental design. In the first case, it is important to measure exudation rates by both seaweed and periphytic algae to estimate the relationship between bacterial production and primary production of both macroalgae and periphyton. Our photosynthesis measurements included both components and its inhibition resulted in a mean reduction of bacterial activity potentially caused by a reduction in carbon uptake by bacteria from periphyton or macroalgal exudate [22]. In addition, primary production is also affected by plant age and environmental conditions. Although there are benefits of measuring bacterial activity under natural conditions [5], it is important to check the effect of biotic and abiotic factors in laboratory conditions controlling variables such as secondary compounds and polymer concentrations of seaweed, periphytic algae and phytoplankton as well as UV intensity, temperature and substrate concentrations.

In conclusion solar light is likely important to bacterial activity in the biofilm but not necessarily as a function of the photosynthetic activity of Sargassum furcatum.

Despite bacterial activity being highest during the afternoon it was not correlated to light intensity. Bacterial activity peaked during the intermediate age of Sargassum when diatoms were abundant in the biofilm, suggesting the importance of periphytic algae.

\section{Acknowledgement}

We thank the IEAPM logistic support, especially to the Department of Oceanography, the Department of Chemistry, Division of Biotechnology Lab team, and 
the comments from the anonymous referee that improve this manuscript. This work was

supported by CAPES, CNPq and FAPERJ.

368

369

\section{References}

370

1. Armstrong E, Yan LM, Boyd KG, Wright PC, Burgess JG (2001) The symbiotic role of marine microbes on living surfaces. Hydrobiologia 461: 37-40. doi: 10.1023/a:1012756913566

2. Bengtsson MM, Sjotun K, Lanzen A, Ovreas L (2012) Bacterial diversity in relation to secondary production and succession on surfaces of the kelp Laminaria hyperborea. Isme Journal 6: 2188-2198. doi: 10.1038/ismej.2012.67

3. Cardinale BJ, Palmer MA (2002) Disturbance moderates biodiversity-ecosystem function relationships: Experimental evidence from caddisflies in stream mesocosms. Ecology 83: 1915-1927.

4. Coelho-Souza SA, Araujo FV, Cury JC, Jesus HE, Pereira GC, Guimaraes JRD, Peixoto RS, Davila AMR, Rosado AS (2015) Bacterial and Archaeal Communities Variability Associated with Upwelling and Anthropogenic Pressures in the Protection Area of Arraial do Cabo (Cabo Frio region - RJ). Anais Da Academia Brasileira De Ciencias 87: 1737-1750. doi: 10.1590/00013765201520140098

5. Coelho-Souza SA, Miranda MR, Salgado LT, Coutinho R, Guimaraes JRD (2013) Adaptation of the H-3-Leucine Incorporation Technique to Measure Heterotrophic Activity Associated with Biofilm on the Blades of the Seaweed Sargassum spp. Microbial Ecology 65: 424-436. doi: 10.1007/s00248-012-01169

6. Coelho-Souza SA, Pereira GC, Coutinho R, Guimaraes JRD (2013) Yearly variation of bacterial production in the Arraial do Cabo protection area (Cabo Frio upwelling region): An evidence of anthropogenic pressure. Brazilian Journal of Microbiology 44: 1349-1357.

7. Coelho-Souza SA, Lopez MS, Davee Guimaraes JR, Coutinho R, Candella RN (2012) Biophysical interactions in the cabo frio upwelling system, southeastern Brazil. Brazilian Journal of Oceanography 60: 353-365.

8. Costerton JW, Lewandowski Z, Caldwell DE, Korber DR, Lappinscott HM (1995) Microbial biofilms. Annual Review of Microbiology 49: 711-745.

9. Croft MT, Lawrence AD, Raux-Deery E, Warren MJ, Smith AG (2005) Algae acquire vitamin B-12 through a symbiotic relationship with bacteria. Nature 438: 90-93. doi: 10.1038/nature04056

10. Duggins DO, Eckman JE (1997) Is kelp detritus a good food for suspension feeders? Effects of kelp species, age and secondary metabolites. Marine Biology 128: 489-495. doi: 10.1007/s002270050115

11. Egan S, Harder T, Burke C, Steinberg P, Kjelleberg S, Thomas T (2013) The seaweed holobiont: understanding seaweed-bacteria interactions. Fems Microbiology Reviews 37: 462-476. doi: 10.1111/1574-6976.12011

12. Ellis CN, Traverse CC, Mayo-Smith L, Buskirk SW, Cooper VS (2015) Character displacement and the evolution of niche complementarity in a model biofilm community. Evolution 69: 283-293. doi: 10.1111/evo.12581

13. Goecke F, Labes A, Wiese J, Imhoff JF (2010) Chemical interactions between 
marine macroalgae and bacteria. Marine Ecology-Progress Series 409: 267-299. doi: 10.3354/meps08607

14. Guimaraens MA, Goncalves JEA, Lourenco SO, Coutinho R (2008) Sensitivity analyses of population biomass dynamics for Ulva spp. and Sargassum furcatum at the Cabo Frio upwelling region of Brazil. Journal of Biological Systems 16: 579-596.

15. Haas AF, Wild C (2010) Composition analysis of organic matter released by cosmopolitan coral reef-associated green algae. Aquatic Biology 10: 131-138. doi: 10.3354/ab00271

16. Hader DP, Kumar HD, Smith RC, Worrest RC (1998) Effects on aquatic ecosystems. Journal of Photochemistry and Photobiology B-Biology 46: 53-68.

17. Hagstrom A, Larsson U (1984) Diel and seasonal variation in growth rates of pelagic bacteria. NATO Conference Series IV Marine Sciences 15: 249-262.

18. Hellio C, Marechal JP, Veron B, Bremer G, Clare AS, Le Gal Y (2004) Seasonal variation of antifouling activities of marine algae from the Brittany coast (France). Marine Biotechnology 6: 67-82. doi: 10.1007/s10126-003-0020-x

19. Hollants J, Leliaert F, De Clerck O, Willems A (2013) What we can learn from sushi: a review on seaweed-bacterial associations. Fems Microbiology Ecology 83: 1-16. doi: 10.1111/j.1574-6941.2012.01446.x

20. Isbell FI, Polley HW, Wilsey BJ (2009) Biodiversity, productivity and the temporal stability of productivity: patterns and processes. Ecology Letters 12: 443-451. doi: 10.1111/j.1461-0248.2009.01299.x

21. Lam C, Stang A, Harder T (2008) Planktonic bacteria and fungi are selectively eliminated by exposure to marine macroalgae in close proximity. Fems Microbiology Ecology 63: 283-291. doi: 10.1111/j.1574-6941.2007.00426.x

22. Lignell R (1990) Excretion of organic-carbon by phytoplankton - its relation to algal biomass, primary productivity and bacterial secondary productivity in the Baltic sea. Marine Ecology Progress Series 68: 85-99. doi: 10.3354/meps068085

23. Miranda MR, Guimaraes JRD, Coelho-Souza AS (2007) [H-3]Leucine incorporation method as a tool to measure secondary production by periphytic bacteria associated to the roots of floating aquatic macrophyte. Journal of Microbiological Methods 71: 23-31. doi: 10.1016/j.mimet.2007.06.020

24. Nair S, Chandramohan D, Bharathi PAL (1992) Differential sensitivity of pigmented and nonpigmented marine-bacteria to metals and antibiotics. Water Research 26: 431-434.

25. Nylund GM, Enge S, Pavia H (2013) Costs and Benefits of Chemical Defence in the Red Alga Bonnemaisonia hamifera. Plos One 8 . doi: 10.1371/journal.pone.0061291

26. Ornellas AB, Coutinho R (1998) Spatial and temporal patterns of distribution and abundance of a tropical fish assemblage in a seasonal Sargassum bed, Cabo Frio Island, Brazil. Journal of Fish Biology 53: 198-208.

27. Parsons TR, Maita Y, Lalli M (1984) A manual of chemical and biological methods for seawater analysis. Pergamon Press, New York

28. Plouguerne E, Hellio C, Cesconetto C, Thabard M, Mason K, Veron B, Pereira RC, da Gama BAP (2010) Antifouling activity as a function of population variation in Sargassum vulgare from the littoral of Rio de Janeiro (Brazil). Journal of Applied Phycology 22: 717-724. doi: 10.1007/s10811-010-9511-0

29. Romani AM, Sabater S (1999) Effect of primary producers on the heterotrophic metabolism of a stream biofilm. Freshwater Biology 41: 729-736. doi: 10.1046/j.1365-2427.1999.00413.x 
30. Skov MW, Volkelt-Igoe M, Hawkins SJ, Jesus B, Thompson RC, Doncaster CP (2010) Past and present grazing boosts the photo-autotrophic biomass of biofilms. Marine Ecology Progress Series 401: 101-111. doi: $10.3354 /$ meps 08481

31. Spilling K, Titelman J, Greve TM, Kuhl M (2010) Microsensor measurements of the external and internal microenvironment of Fucus vesiculosus (phaeophyceae). Journal of Phycology 46: 1350-1355. doi: 10.1111/j.15298817.2010.00894.x

32. Steinberg PD, Rice SA, Campbell AH, McDougald D, Harder T (2011) Interfaces Between Bacterial and Eukaryotic "Neuroecology". Integrative and Comparative Biology 51: 794-806. doi: 10.1093/icb/icr115

33. Strickland JD, Parsons TR (1972) A pratical handbook of seawater analysis. Bulletin Fisheries Research Canadian

34. Valentin JL (1984) Analysis of hydrobiological parameters in the cabo frio (brazil) upwelling. Marine Biology 82: 259-276.

35. Wahl M (1989) Marine epibiosis .1. Fouling and antifouling - some basic aspects. Marine Ecology Progress Series 58: 175-189. doi: 10.3354/meps058175 
514 Figure 1: Seasonal bacterial activity (mean $\pm \mathrm{SE}$ ) at different times of the day during

515 Sargassum growth between November/2007 and April/2008 (n=5).

516 Figure 2: Mean of bacterial activity at different levels of light during Sargassum growth 517 in the experiments done between November/2007 and April/2008 (top) (n=5); and its 518 relationship with light intensity pooling all data (bottom) $(n=3)$.

519 Figure 3: Mean \pm SE of bacterial activity $\left(\mathrm{pgC} . \mathrm{cm}^{-2} \cdot \mathrm{h}^{-1}\right)$ at different times of the day 520 under the presence or absence of diuron in the experiments undertaken in 521 December/2007, February and April/2008 (n=5).

522 Figure 4: Mean \pm SEM of biofilm heterotrophic activity in different times of a day and 523 under different levels of light during the afternoon $(\mathrm{n}=5)$ as well as in Sargassum 524 autototrophic production under different levels of light during the afternoon $(n=3)$ with 525 and without the antibiotic streptomycin (left) and chloramphenicol (right) during the 526 experiments conducted in January/08. 


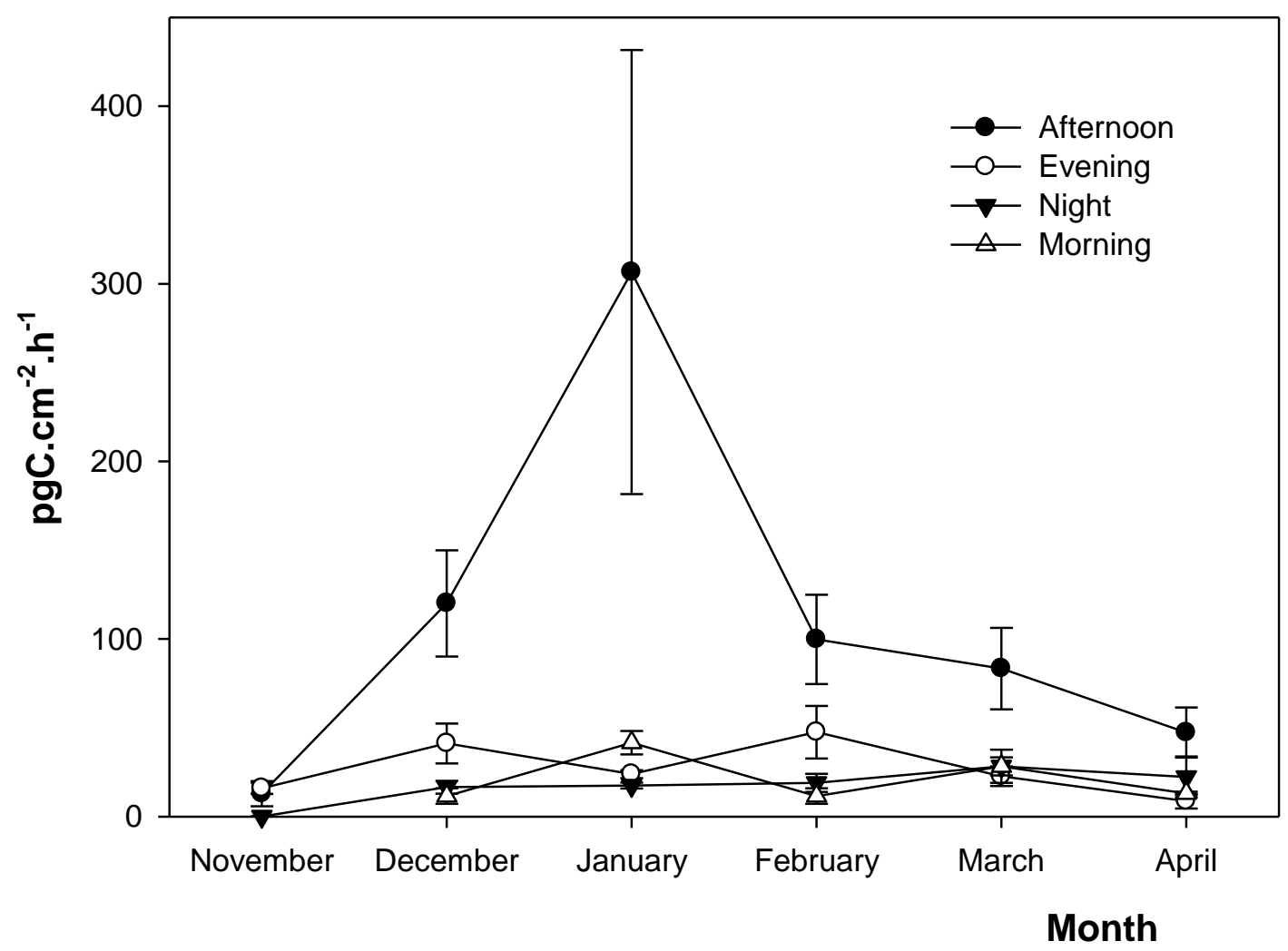

Figure 1: Seasonal bacterial activity (mean $\pm \mathrm{SE}$ ) at different times of the day during Sargassum growth between November/2007 and April/2008 ( $\mathrm{n}=5)$. 

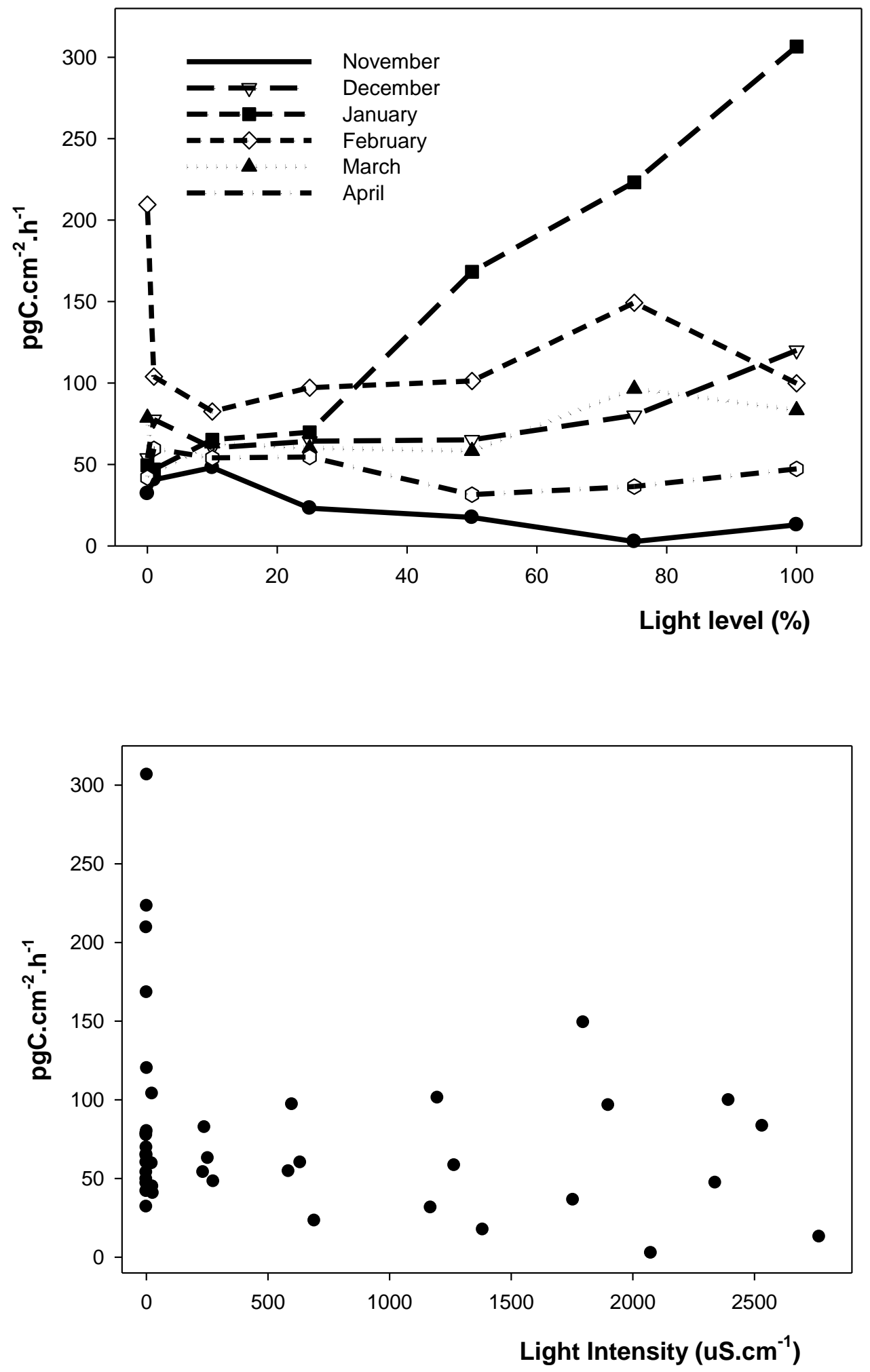

Figure 2: Mean of bacterial activity at different levels of light during Sargassum growth in the experiments done between November/2007 and April/2008 (top) (n=5); and its relationship with light intensity pooling all data (bottom) $(n=3)$. 

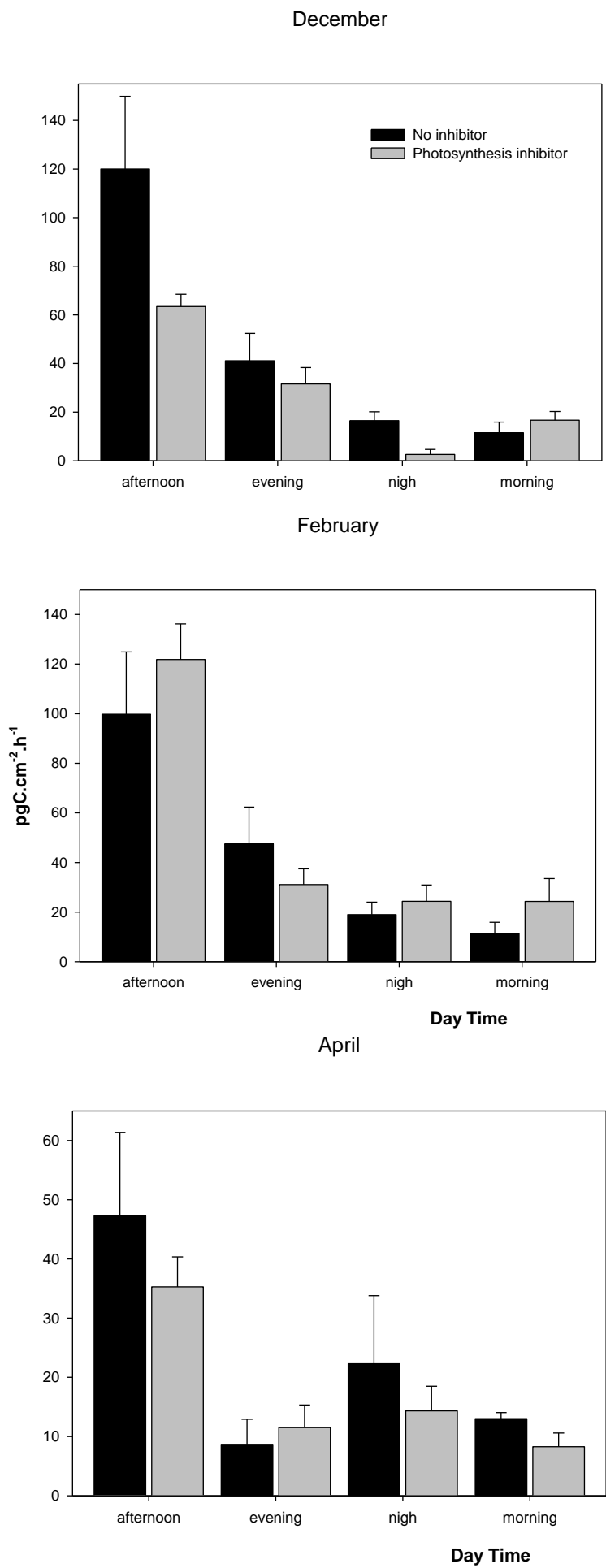

Figure 3: Mean \pm SE of bacterial activity $\left(\mathrm{pgC} \cdot \mathrm{cm}^{-2} \cdot \mathrm{h}^{-1}\right)$ at different times of the day under the presence or absence of diuron in the experiments undertaken in December/2007, February and April/2008 (n=5). 
Heterotrophic activity

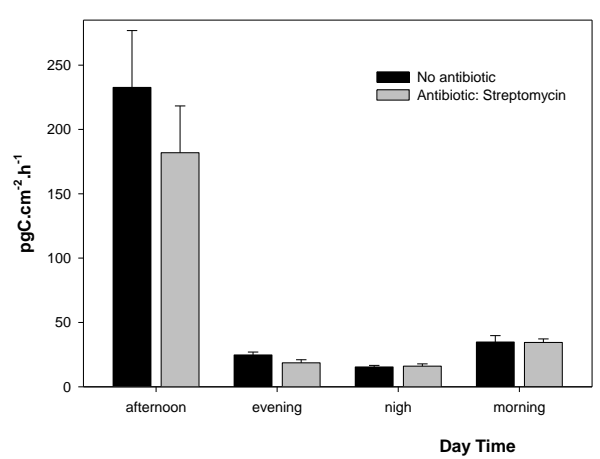

Heterotrophic Activity

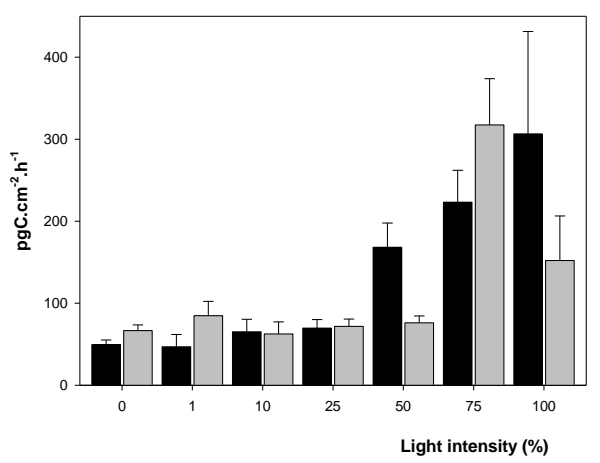

Autotrophic Production

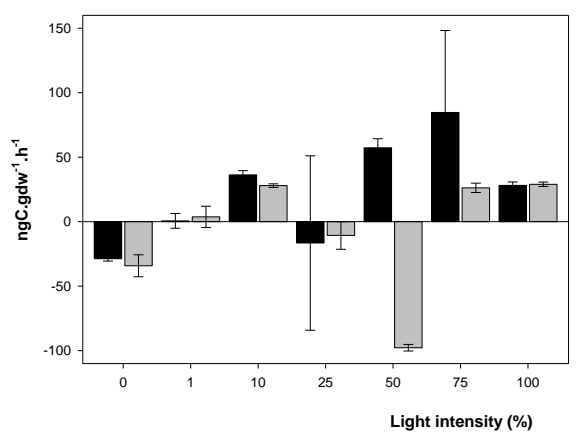

Heterotrophic Activity

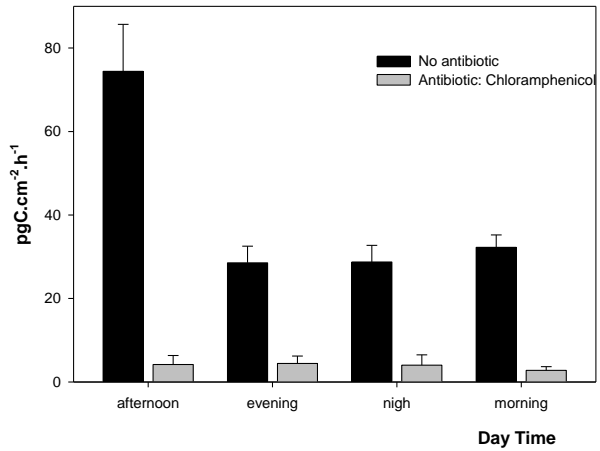

Heterotrophic Activity

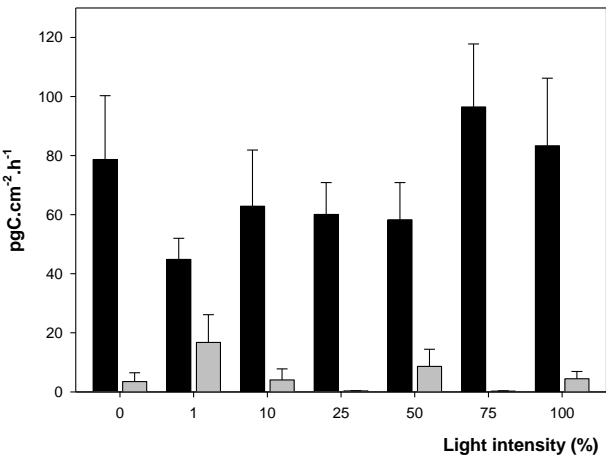

Autotrophic Production

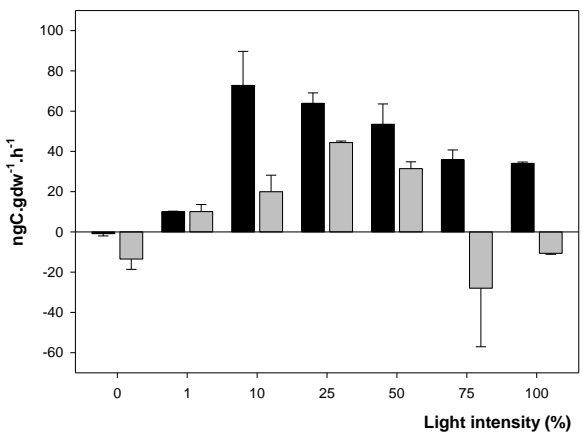

Figure 4: Mean \pm SEM of biofilm heterotrophic activity in different times of a day and under different levels of light during the afternoon $(n=5)$ as well as in Sargassum autototrophic production under different levels of light during the afternoon $(n=3)$ with and without the antibiotic streptomycin (left) and chloramphenicol (right) during the experiments conducted in March/08. 
Table 1: The use of antibiotics (penicillin, streptomycin and chloramphenicol) and photosynthesis inhibitor (diuron) in both autotrophic production and bacterial activity for the experiments realized during the Sargassum growth cycle.

\begin{tabular}{ccc}
\hline $\begin{array}{c}\text { Month of the } \\
\text { Experiment }\end{array}$ & Autotrophic production & Bacterial Activity \\
\hline November & No inhibitor & Penicillin + Streptomycin \\
December & Penicillin + Streptomycin & Diuron \\
January & Streptomycin & Streptomycin \\
February & Diuron & Diuron \\
March & Chloramphenicol & Chloramphenicol \\
April & Diuron & Diuron \\
\hline
\end{tabular}

Table 2: Physical-chemical variables measured in surface and deep waters during the sampling and experimental dates.

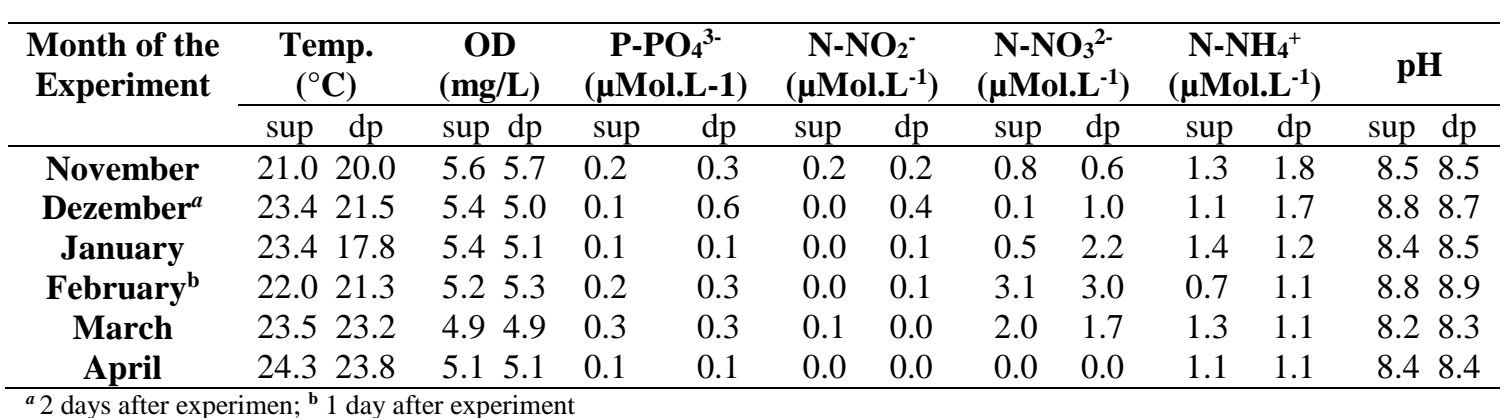

Table 3: Concentration of chlorophylls in surface and deep waters during the sampling and experimental dates.

\begin{tabular}{|c|c|c|c|c|c|c|c|c|}
\hline \multirow[t]{2}{*}{$\begin{array}{l}\text { Month of the } \\
\text { Experiment }\end{array}$} & \multicolumn{2}{|c|}{ Chlorophyll- $a$} & \multicolumn{2}{|c|}{ Chlorophyll-b } & \multicolumn{2}{|c|}{ Chlorophyll-c } & \multicolumn{2}{|c|}{ Pheofitin } \\
\hline & sup & $\mathrm{dp}$ & sup & $\mathrm{dp}$ & sup & $\mathrm{dp}$ & sup & $\mathrm{dp}$ \\
\hline November & 0.9 & 0.9 & 0.2 & 0.2 & 0.3 & 0.1 & 0.3 & 0.9 \\
\hline Dezember $^{a}$ & 1.8 & 1.6 & 0.0 & 0.0 & 0.0 & 0.6 & 2.8 & 0.0 \\
\hline January & 0.6 & 0.5 & 0.0 & 0.0 & 0.0 & 0.0 & 1.3 & 0.3 \\
\hline February $^{b}$ & 1.0 & 0.7 & 0.1 & 0.2 & 0.5 & 0.3 & 0.0 & 0.0 \\
\hline March & 0.3 & 0.0 & 0.0 & 0.0 & 0.0 & 0.0 & 0.0 & 0.1 \\
\hline April & 0.6 & 0.3 & 0.0 & 0.0 & 0.0 & 0.0 & 0.6 & 0.0 \\
\hline
\end{tabular}

${ }^{a} 2$ days after the experiment; ${ }^{\mathbf{b}} 1$ day after the experiment

Table 4: Range in the reduction of bacterial activity (\%) under the presence of photosynthesis inhibitor (diuron) in experiments in the daily cycle and simulating light extinction during the afternoon.

\begin{tabular}{cccc}
\hline Month & Daily cycle & Afternoon & Significant effect \\
\hline November & $13-66$ & $0-81$ & $50 \%$ of light \\
December & $0-59$ & $0-47$ & afternoon and night \\
February & $0-40$ & $0-44$ & ns \\
April & $0-39$ & $0-25$ & morning and night \\
\hline
\end{tabular}

